Original Paper

\title{
Upaya Peningkatan Produksi Kentang Melalui Penggunaan Benih Bersertifikasi di Kawasan Sembalun, Kabupaten Lombok Timur
}

\author{
Muhammad Sarjan ${ }^{1 *}$, Kisman², Farid Hemon ${ }^{2}$ \\ 1 Program Studi Pengelolaan Sumberdaya Lahan Kering, Pascasarjana, Universitas Mataram, Mataram, \\ Indonesia. \\ 2 Program Studi Agroekoteknologi, Fakultas Pertanian, Universitas Mataram, Mataram, Indonesia
}

DOI: $10.29303 /$ jpmpi.v3i1.400

Sitasi: Sarjan, M., Kisman, K., \& Hemon, F. (2020). Upaya Peningkatan Produksi Kentang Melalui Penggunaan Benih Bersertifikasi di Kawasan Sembalun, Kabupaten Lombok Timur. Jurnal Pengabdian Magister Pendidikan IPA, 3(1). doi:https://doi.org/10.29303/jpmpi.v3i1.400

*Corresponding Author:

Muhammad Sarjan,

Program Studi

Pengelolaan Sumberdaya

Lahan Kering,

Pascasarjana, Universitas

Mataram, Mataram,

Indonesia;

Email:

m_sarjan@unram.ac.id
Abstrak: Melalui kegiatan pengabdian pada Masyarakat ini Perguruan Tinggi ingin membantu diseminasi produksi benih kentang yang bermutu bersertifikat dan menjadikan kelompok tani sebagai penangkar benih (Seed Grower) yang handal secara berkelanjutan. Keberadaan penangkar benih ini diharapkan dapat mensuplai benih pada budidaya kentang khususnya ditingkat lokal kawasan Sembalun. Adanya penangkar Benih kentang ini sekaligus dapat meningkatkan income generating dari Kelompok Petani penangkar dan permasahan penyediaan benih bermutu untuk petani di Kawasan Sembalun khususnya dan di Kabupaten Lombok Timur pada umumnya dapat diatasi. Selanjutnya penggunaan benih bermutu bersertifikasi diharapkan juga dapat meningkatkan produksi kentang dan akhirnya dapat meningkatkan pendapatan petani. Berdasarkan hasil kegiatan dan evaluasi yang dilakukan antara lain diperoleh bahwa Penyuluhan yang diikuti dengan demonstrasi Plot budidaya benih kentang bersertifikat bagi Masyarakat Kelompok Tani Calon Penangkar Benih di Desa Sembalun Bumbung- Lombok Timur dapat meningkatkan minat, pengetahuan dan keterampilan masyarakat petani dalam pengembangan benih Kentang bersertifikat, sehingga produksi dan kualitas kentang yang dihasilkan menjadi lebih baik. Masyarakat desa Sembalun Bumbung mempunyai motivasi yang tinggi untuk mengusahakan tanaman kentang termasuk minat yang cukup tinggi untuk menjadi penangkar benih kentang. Untuk keberlanjutan usaha perbenihan disarankan antara lain perlunya pengawasan dan bimbingan yang terus menerus kepada petani penangkar benih kentang di Desa Sembalun Bumbung terutama dari pihak terkait seperti BPSB sehingga kelas atau mutu dan kualitas benih kentang yang dihasilkan menjadi lebih baik dan lebih profesional sebagai penagkar benih. Disarankan kepada para petani calon penangkar benih kentang agar terus meningkatkan kualitas benih yang dihasilkan dengan cara melengkapi sarana dan prasarana seperti penyiapkan gudang penyimpanan benih.

Kata Kunci: Benih Kentang; sertifikat; Penangkar; Sembalun. 


\section{Pendahuluan}

Upaya peningkatan produksi kentang di Indonesia dihadapkan pada kendala yang berhubungan dengan manajemen produksi dan ketersediaan benih bermutu yang sangat terbatas (Ranu, 2009). Sampai dengan tahun 2008, produksi benihkentang nasional baru bisa memenuhi hanya $8,3 \%$, sehingga sisanya dipenuhi dari oleh benih impor (1 \%) dan lebih dari $90 \%$ dipenuhi dengan benih yang diproduksi oleh petani tanpa asal usul yang jelas (Anonim, 2009). Benih kentang yang diimpor adalah benih kentang Atlantis ,sedangkan benih kentang produksi nasional umumnya adalah benih varietas Atlantis dan Granola serta beberapa varietas lokal lainnya Penangkar benih kentang terbesar di Indonesia adalah daerah Jawa Barat, Sumatra Utara dan Jambi, Jawa Tengah yang masih jauh dibawah kebutuhan benih, dan menunjukkan bahwa produksinya bahkan belum mencukupi kebutuhan benih lokal di provinsi produsennya.

Tingginya permintaan dan rendahnya produksi benih ini menunjukkan besarnya potensi secara nasional akan kebutuhan benih bersertifikat tersebut. Meskipun terdapat kompetitor, akan tetapi peluang pasar masih jauh lebih besar. Kompetitor lain adalah produsen benih impor, namun ketersediaan benih impor juga terkendala berbagai persoalan termasuk kontinuitas ketersediaan, terbawanya penyakit, masalah karantaina dan lainnya.

Langkah strategis untuk mengatasi hal tersebut adalah pengembangan perbenihan kentang nasional bersertifikat melalui pengembangan sentra yang telah terbentuk dan kawasan baru potensial, seperti Kawasan Sembalun NTB yang memiliki kesesuaian agroklimat dan keunggulan kompetitif wilayah karena terbebas dari Nematoda Sista Kuning (NSK), penyakit yang sangat ditakuti oleh petani kentang dunia. Meskipun telah dilakukan pembinaan calon penangkar oleh instansi berwenang (Anonim, 2010), upaya produksi benih kentang bersertifikat di NTB belum berhasil. Penyebabnya antara lain adalah keterbatasan penguasan teknologi dan belum terbentuknya rantai sistem produksi di NTB yang meliputi produksi plantlet bebas virus melalui kultur jaringan, produksi umbi Go (Benih penjenis), G1 dan G2 (Benih Dasar) serta benih G3 (Benih Pokok) dan G4 (Benih sebar) serta dibarengi dengan pengujian dan sertifikasi benih (Abdurrachman, 2000; Suwarno, 2008). Disisi lain, Universitas Mataram yang memiliki teknologi tersebut dan telah berhasil memprodukdi bibit kentang bebas virus melalui kultur jaringan. Universitas Mataram telah bersinergi dengan BBI TPH untuk memproduksi benih Go bebas virus, dan rantai produksi G1 sampai G3 telah terbentuk melalui kegiatan RUSNAS 2013-2015 dan dihasilkan benih kentang bersertifikat dari Nusa Tenggara Barat.

Kelembagaan yang ada di tingkat petani (kelompok tani) memiliki potensi yang cukup baik untuk dilakukan pembinaan penangkaran perbenihan. Jika penangkaran benih bisa berkembang di tingkat kelompok tani maka kebutuhan akan benih dapat dipenuhi oleh kelompok tani tersebut, sehingga biaya pengadaan benih relatif lebih murah dan akan menambah pendapatan bagi kelompok tani. Dengan demikian keberadaan benih tidak terlalu jauh dari pengguna, sehingga para petani mudah mendapatkan benih yang bermutu, dan juga memberikan nilai tambah bagi kelompok tani. Kecamatan Sembalun merupakan salah satu kecamatan di Kabupaten Lombok Timur yang memiliki potensi pengembangan budidaya hortikultura dataran tinggi termasuk kentang dengan daya dukung sumberdaya alam yang melimpah dan tingkat kesesuaian lahan yang cocok untuk tumbuh dan berkembangnya tanaman kentang dengan optimal

Melalui kegiatan pengabdian pada Masyarakat ini Perguruan Tinggi ingin membantu melalui diseminasi produksi benih kentang yang bermutu bersertifikat dan menjadikan kelompok tani sebagai penangkar benih (Seed Grower) yang handal secara berkelanjutan. Keberadaan penangkar benih ini diharapkan dapat mensuplai benih pada 
budidaya kentang khususnya ditingkat lokal kawasan Sembalun. Adanya penangkar Benih kentang ini sekaligus dapat meningkatkan income generating dari Kelompok Petani penangkar dan permasahan penyediaan benih bermutu untuk petani di Kawasan Sembalun khususnya dan di Kabupaten Lombok Timur pada umumnya dapat diatasi. Selanjutnya penggunaan benih bermutu bersertifikasi diharapkan juga dapat meningkatkan produksi kentang dan akhirnya dapat meningkatkan pendapatan petani.

\section{Metode}

Kegiatan ini dilaksanakan di Kawasan Agrowisata Sembalun Kabupaten Lombok Timur, dan lokasi yang dipilih adalah Desa yang merupakan sentra produksi tanaman kentang. Peserta terdiri atas petani yang yang tergabung dalam kelompok penangkar beni kentang dan kelompok tani kentang.

Metode yang digunakan dalam kegiatan ini adalah metode kaji tindak (Action Research) dengan menerapkan pendekatan program tindak partisipatif (Partisipatory Action Program) dari peserta melalui diskusi, dan kerja kelompok pada seluruh kegiatan. Tahapan dalam kegiatan ini meliputi tahapan persiapan, antara lain identifikasi masalah, kemudian survey pendasaran menggunakan metode deskriptif eksploratif. Tahapan pelaksanaan, diawali dengan pelatihan dengan teknik ceramah. Materi pelatihan yang

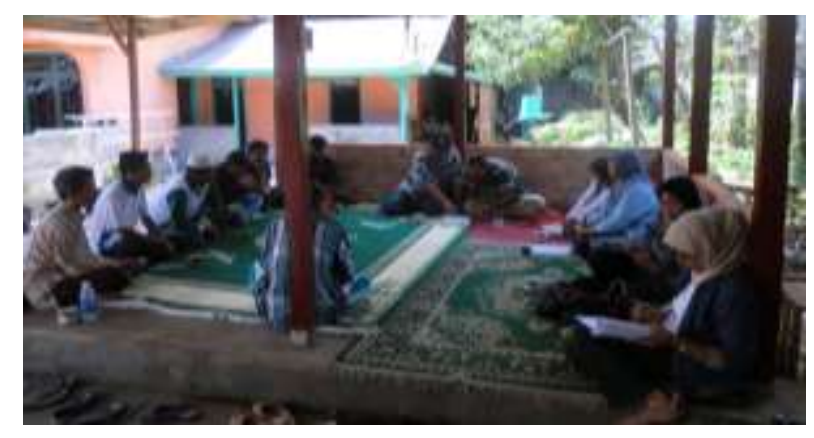

disampaikan meliputi Teknik Budidaya Kentang secara umum, Proses dan rantai produksi benih kentang.

Penialaian terhadap kegiatan ini dilakukan dengan berpedoman pada 1) kesesuaian antara topik action research yang dilaksanakan dengan keadaan lokasi kegiatan, 2) kehadiran dan partisipasi para peserta (sasaran) terhadap setiap kegiatan sejak dari persiapan sampai berakhirnya kegiatan mencerminkan keinginan dari peserta untuk mengetahui dan mengadopsi teknologi yang diperkenalkan oleh Tim pelaksana, dan 3) sikap dan tanggapan dari para peserta terhadap kegiatan yang dilaksanakan.

\section{Hasil dan Pembahasan}

\section{Kegiatan Ceramah dan Diskusi}

Kegiatan Ceramah yang dihadiri oleh anggota Kelomok Tani Penangkar Benih Kentang Lumbung Hijau, Smbalun Bumbung, disampaikan secara garis besar materi tentang Perbenihan Kentang, Teknik Budidaya Kentang dan Pengendalian Hama dan Penyakit Tanaman Kentang. Para peserta diskusi sangat bersemangat mendengarkan dan mencermati penyampaian materi yang dibawakan oleh Tim. Di samping dapat dilihat dari kehadiran peserta, juga dari interaksi peserta dengan Tim selama diskusi. Dimana para peserta banyak menanyakan hal hal yang berkaitan dengan pengalaman mereka di lapangan.

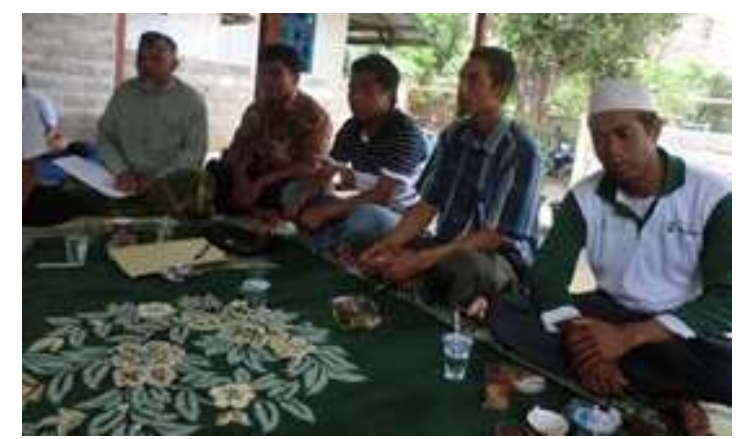

Gambar 1. Kegiatan Ceramah dan Diskusi pada Kelompok Penangkar Benih Kentang Lumbung Hijau, Desa Sembalun Bumbung. 


\section{Demonstrasi Plot Budidaya Kentang}

Plot Budidaya Kentang di Desa Sembalun Bumbung didemontrasikan seperti Gambar 2.
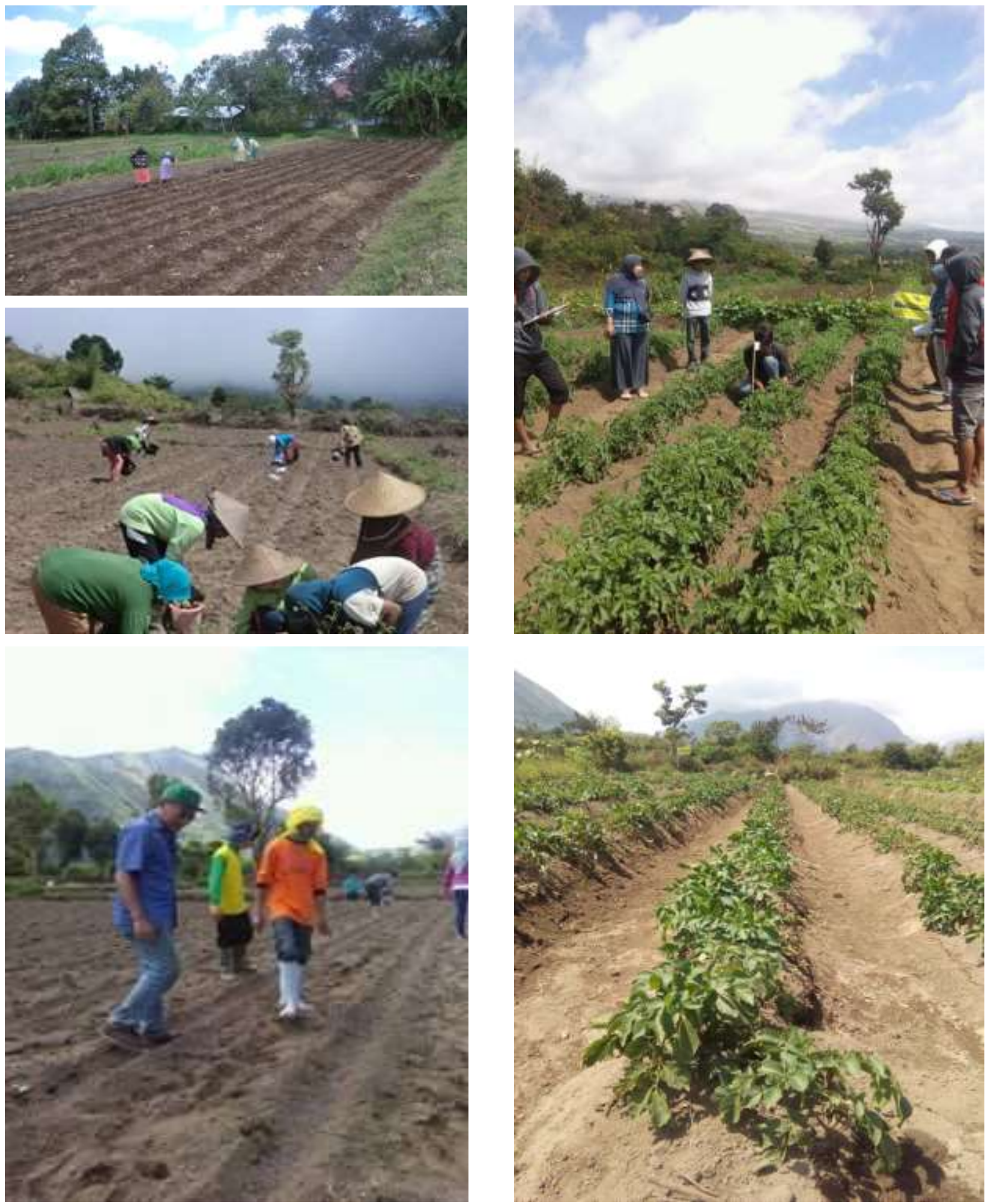

Gambar 2. Penyiapan Lahan, Penanaman, dan Tanaman Kentang Umur 65 Hari Setelah Tanam ( HST) 


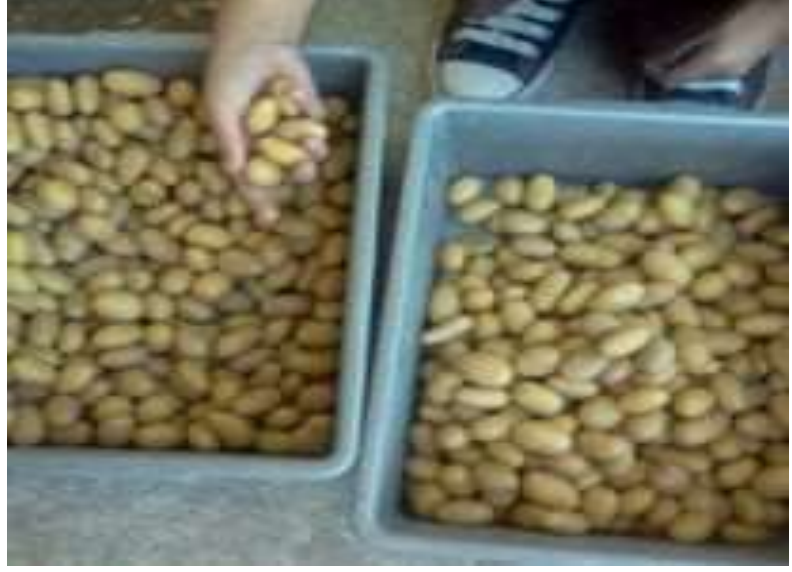

(A)

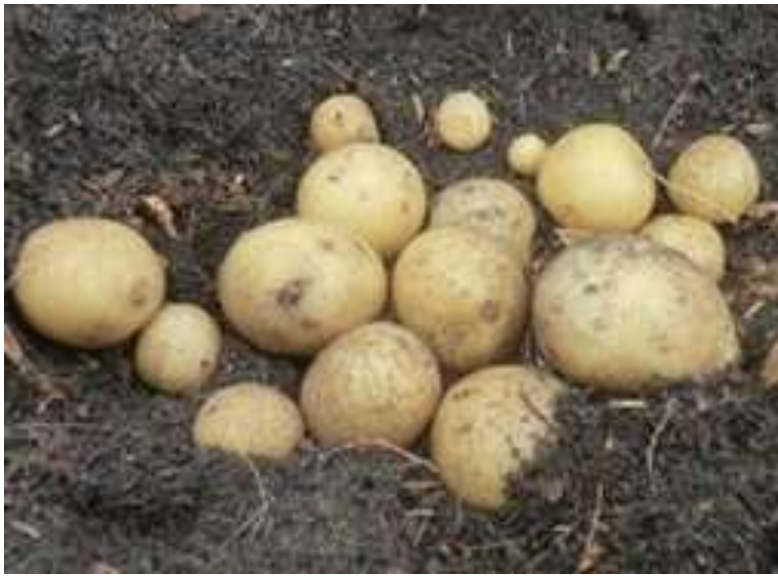

(B)

Gambar 3. Benih Kentang G 2 ( A) an Benih Kentang G3 (B)

\section{Pengamatan Kegiatan Budidaysa Benih Kentang}

Pengamatan dilakukan bersama sama antara Tim Pelaksana dan Anggota kelompok Tani, secara regular selama masa pertumbuhan Tanaman Kentang. Dari hasil pengamatan tersebut tim pelaksana menyempaikan penjelasan hal-hal penting ya ng berkaitan dengan budidaya terutama tentang produksi benih kentang. Benih kentang G2 yang ditanam berasal dari hasil penelitian RUSNAS bersama dengan salah satu penangkar benih yang sebelumnya dihasilkan G1 oleh UNRAM dan BBI. Kemudian pada penanaman bersama kelompom saat ini akan menghasilkan G3 yang selanjutnya akan disebarkan kepada petani, sebagai benih sebar. Disampaikan kepada peserta bahwa penanaman kentang konsumsi pada prinsdipnya sama dengan teknik budidaya benih. Namun ada beberapa hal penting yang perlu diperhatikan antara lain, benih harus bebas dari penyakit NSK, dan selama pertumbuhannya perlu dilakukan Roging untuk menghindari adanya pertumbuhan yang menyimpang yang akan mempengaruhi kemurnian benih. Selanjutnya hal yang perlu dilakukan untuk menghasilkan benih kentang bersertifikasi, petani penagkar harus mendaftarkan ke pihak BPSB TPH NTB untuk didaftar dan akan dilakukan pemantauan oleh pihak BPSB TPH, sebelum dikeluarkan sertifikat benih kentang.

\section{Analisa Kegiatan Penyuluhan dan Demplot}

Kegiatan Penyuluhan dan Demplot Produksi benih kentang bersertifikat di Desa Sembalun Bumbung Kecamatan Sembalun Kabupaten Lombok Timur diikuti oleh petani yang merupakan perwakilan dari masingmasing Kelompok. Proses kegiatan pelatihan ini cukup berhasil berdasarkan indikator kehadiran peserta selama 1 hari penyuluhan, yang dimulai pada jam 8.00 pagi sampai jam 17.00 WITA. Pada awal pelaksanaan kegiatan penyuluhan, pengetahuan dasar peserta tentang teknik budidaya benih kentang bersertifikat masih beragam ada yang cukup baik ada yang masih rendah, rata-rata tergolong rendah karena belum pernah mengikuti pelatihan pelatihan serupa. Sebagian dari mereka menganggap produksi benih kentang bersertifikat sama dengan teknik produksi kentang konsumsi.

Motivasi peserta untuk mengikuti kegiatan pelatihan cukup tinggi dan terus meningkat sampai akhir kegiatan. Hal ini ditandai dengan tingkat kehadiran peserta yang tidak pernah absen, begitu juga antusiasme peserta yang tinggi selama pelatihan dengan semakin banyaknya peserta yang mengangkat tangan untuk bertanya dan berdiskusi. Sebagian besar peserta pelathan 
cukup kritis dalam memberikan ide, gagasan, dan sharing pengalaman dengan fasilitator maupun dengan anggota peserta pelatihan yang lain.

\section{Faktor Pendorong dan Penghambat.}

Beberapa faktor yang dapat mendukung pengembanganbenih kentang di desa Sembalun Bumbung kecamatan Sembalun kabupaten Lombok Timur adalah sumberdaya lahan. Desa Sembalun Bumbung merupakan salah satu desa di kecamatan Sembalun kabupaten Lombok Timur yang sebagian besar daerah atau lahan pertaniannya sangat subur, terutama untuk pengembangan hortikultura dataran Tinggi. Semua lahan merupakan lahan iyang intensif ditanami berbagai komoditas hortikultura termasuk kentang. Hanya saja lahan potensial tersebut belum dikelola dengan optimal. Kondisi lahan tersebut sangat potensial untuk pengembangan kentang, termasuk untuk usaha penangkaran benih kentang.

Para peserta juga sangat tertarik dengan diperkenalkan beberapa varietas kentang unggul baru dan keinginan yang tinggi dari mereka untuk menggunakan varietas kentang unggul baru selain yang sduah diusahakan selama ini yaitu caritas Granola dan Atlantis. Selain itu para peserta juga sudah memahami penggunaan benih bersrtifikat, sehingga penggunaan benih kentang bersertifikat pada kegiatan demplot semakin meningkatkan motivasinya sebagai produsen benih di masa yang akan datang.

Keberhasilan dari pelaksanaan kegiatan ini sangat dipengaruhi motivasi dan respon positif masyarakat yang tergabung dalam kelompok tani peserta penyuluhan dan demplot untuk menerima adopsi teknologi budidaya kentang $i$, serta mengembangkannya sebagai peluang berusaha dan peluang untuk meningkatkan pendapatan. Disamping itu, dukungan aparat desa dan respon masyarakat di sekitar lokasi sangat baik. Karena kelompok tani peserta pernah mendapatkan pelatihan dari berbagai institusi atas bimbingan instruktur, maka hal ini juga menjadi faktor pendorong, dimana antara peserta dengan instruktur sudah saling mengenal secara emosional. Dengan demikian peserta sangat antusias untuk menerapkan teknologi yang diterapkan untuk mencapai tujuannya yaitu sebagai penangkar benih kentang.

\section{Kesimpulan}

Berdasarkan hasil kegiatan dan evaluasi yang dilakukan maka dapat disimpulkan: 1) Penyuluhan yang diikuti dengan demonstrasi Plot budidaya benih kentang bersertifikat bagi Masyarakat Kelompok Tani Calon Penangkar Benih di Desa Sembalun Bumbung-Lombok Timur ini dapat meningkatkan minat, pengetahuan dan keterampilan masyarakat petani di Desa Sembalun Bumbung kecamatan Sembalun kabupaten Lombok Timur dalam pengembangan benih Kentang bersertifikat, sehingga produksi dan kualitas kentang yang dihasilkan menjadi lebih baik. 2) Masyarakat desa Sembalun Bumbung mempunyai motivasi yang tinggi untuk mengusahakan tanaman kentang termasuk minat yang cukup tinggi untuk menjadi penangkar benih kentang.

\section{Ucapan Terimakasih}

Penulis mengucapkan terima kasih kepada Universitas Mataram melalui Lembaga Penelitian dan Pengabdian Kepada Masyarakat yang telah memberi dukungan financial terhadap kegiatan Pengabdian ini.

\section{Daftar Pustaka}

Abdurrachman. (2000). Sertifikasi benih kentang menjamin kebenaran kualitas

Anonim. (2009). Program Unggulan Dinas Pertanian Provinsi Nusa Tenggara Barat, Pemda NTB. 
Anonim. (2010). Peningkatan Kapasitas Petani Untuk Menjadi Penangkar Benih Kentang di Kawasan Sembalun Lombok Timur. BPTP Provinsi NTB.

Ranu N.L. (2009). Aturan Perbenihan dan Pengembangan Industri Benih Kentang di Indonesia. Direktorat Jenderal Hortikultura. Kementerian Pertanian Republik Indonesia.

Suwarno W.B. (2008). Sistem Perbenihan Kentang di Indonesia. Ditulis tahun 2000 dan dipubilkasikan kembali tahun 2008 melalui http://www.situshijau.co.id. Instutut Pertanian Bogor. 